\title{
Erfaringer med vejledning i studenterprojekter med eksterne samarbejdspartnere
}

\author{
Jens E. Wilhjelm, lektor ved Ørsted·DTU, Danmarks Tekniske Universitet
}

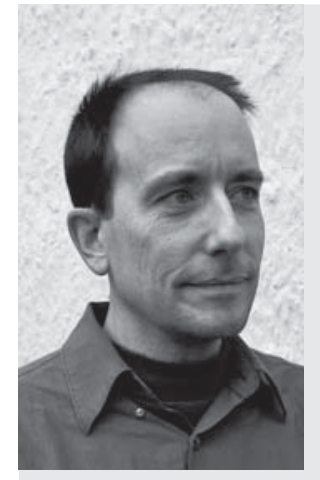

Jens E. Wilhjelm er uddannet civilingeniør fra DTU og ph.d. i medikoteknik fra Worcester Polytechnic Institute, Massachusetts, USA. Han er lektor i medikoteknik ved Ørsted·DTU, Danmarks Tekniske Universitet og medstifter af uddannelsen Medicin og Teknologi. Har siden 199| været vejleder i en lang række specialkurser, polytekniske midtvejsprojekter, bachelorprojekter og eksamensprojekter.

Han er endvidere kandidatstudieleder for studiet Medicin og Teknologi. Herudover underviser han på to af kurserne på bacheloruddannelsen, hvortil han også er medforfatter til de anvendte elektroniske lærebøger. Den ene er under omskrivning i et projekt tilknyttet LearningLab.DTU. Er endvidere pædagogisk konsulent for LearningLab·DTU.

Inddragelse af eksterne partnere i studenterprojekter er ofte vardifuldt for både den studerende, vejlederen og ikke mindst den eksterne part (firma, hospital, etc.). Fordele og ulemper ved sådanne projekter behandles, og der gives en oversigt over nogle af de forhold, man som vejleder skal vare opmorksom på.

\section{Det motiverende studenterprojekt}

I denne artikel belyses en række af de aspekter, som knytter sig til vejledning af studenterprojekter - med særligt fokus på projekter med eksterne partnere. Grundlaget er erfaringer fra civilingeniøruddannelser på DTU. Studenterprojekter kan være specialkurser samt bachelorprojekt og kandidatprojekt ${ }^{1}$, som laves sidst i studiet. I nævnte rækkefølge adskiller de sig ved at strække sig over længere tid og stille større krav. Nærværende artikel har primært fokus på bachelor- og kandidatprojekter.
De eksterne samarbejdspartnere kan være (sektor-) forskningsinstitutioner og universiteter, andre offentlige institutioner, såsom hospitaler og kommuner, samt private virksomheder. Når disse specifikke benævnelser bruges nedenfor i stedet for det generelle »eksterne partnere", så antyder de en lidt større repræsentation af denne part.

Et studenterprojekts fremmeste formål er at udvikle den studerende gennem arbejdet med et konkret projekt. Ud over at være på et passende fagligt niveau kræver et godt studenterprojekt motiverede studerende, hvilket kan tilstræbes på en lang række måder. Stor motivation kommer blandt andet fra den studerendes følelse af ejerskab og ansvar for sit projekt samt følelsen af støtte fra omgivelserne (herunder vejlederne). Det er også vigtigt, at projektet er fagligt spændende og passende udfordrende for den studerende. Gode samfundsmæssige og personlige perspektiver er også fordelagtige, for eksempel ved at projektet afspejler den verden, som den studerende skal ud i. Endvidere er det vigtigt med adgang til gode ressourcer og værktøjer, såsom computere, programmel, instrumenter, værkstedsstøtte osv.. Slutteligt må den studerende meget gerne føle interesse fra vejlederne og de andre interessenter, som denne møder. Allerbedst er det, hvis ens resultater direkte skal bruges af andre i en forskningsmæssig eller praktisk sammenhæng.

Mange af disse kriterier for et godt projekt tilgodeses ved projekter i samarbejde med eksterne partnere. I forbindelse med den slags projekter kan man imidlertid spørge, hvad det betyder for vejledningen af studerende, at der er eksterne interessenter knyttet til projektet, og herunder for eksempel om de studerende føler sig mere forpligtede og dermed mere tilbøjelige til at overholde aftaler, eller om vejledningen vanskeliggøres af, at der er flere parter involveret, og af at de studerende måske fysisk er mere på afstand? Dette og mange andre spørgsmål søges besvaret her. 


\section{Håndtering af projekter på ingeniøruddannelsen Medicin og Teknologi}

På baggrund af vores mangeårige gode erfaringer med at udbyde projekter med eksterne samarbejdspartnere primært hospitaler og medikotekniske virksomheder har vi siden 2005 i den nye uddannelse i Medicin og Teknologi (fra 2003) sat projekter med eksterne samarbejdspartnere i system. ${ }^{2}$ I starten af efterårssemesteret indsamles projektforslag fra medikotekniske virksomheder og hospitaler. Disse udbydes i oktober til de cirka 50 studerende på en projekteftermiddag, hvor de studerende presenteres for projekterne og møder projektstillerne. Alle projekter er specifikke opgaver, som projektstillerne ønsker løst. De studerende vælger så det projekt, de finder mest interessant (der er lodtrækning, hvis flere melder sig) og udfører projektet det følgende forår. I foråret 2006 udførtes 15 projekter med 38 studerende fordelt med 1 til 4 studerende per projekt.

I ovennævnte tilfælde fremkommer projekterne ved, at universitetet spørger de eksterne partere; $i$ andre tilfælde har den/de studerende selv fundet den eksterne part og søger derfor blot en vejleder på universitetet.

\section{Fordele, ulemper og udfordringer ved projekter med eksterne partnere}

\section{Fordele}

Set med universitetsvejlederens øjne er der en række fordele ved projekter med eksterne partnere. Nogle af de mere oplagte er: 1) Vejledningsbyrden bliver - i princippet - fordelt over flere, hvilket betyder en mindre indsats af den akademiske vejleder. Endvidere bliver mængden af vejlederkompetencer øget, idet den eksterne vejleder ofte vil sidde inde med kompetencer, som supplerer og udstrækker den universitetsansattes. 2) Opgaven vil normalt altid være meget relevant at få løst og dermed motiverende for den studerende. 3) Den studerende føler et større ansvar og antageligvis også et større præstationspres, når projektet også vurderes af en person, som måske kan have betydning for den senere karriere. 4) I den udstrækning (forsøgs)arbejdet foregår hos den eksterne part, aflastes vejlederen (og instituttet) for opgaver i denne forbindelse.

\section{Ulemper}

Set med vejlederøjne er der også forbundet en række ulemper, hvoraf kan nævnes: 1) Vejlederen kan i lighed med den studerende opleve et øget pres med hensyn til projektets kvalitet, når der er eksterne øjne, der kigger med. 2) Vejlederen er nødt til at bruge mere tid på møder, da der ofte er mere, der skal koordineres og møderne kan ikke altid foregå på vejlederens kontor. 3) Den eksterne part skal gøres opmærksom på, at den opgave denne stiller, ikke nødvendigvis bliver "øst". Nogle gange lykkes det, men da der er stor forskel på de studerende - og det da kan være svært at forudsige, hvor lang tid et projekt tager - er der ingen garanti for, at "varen leveres" hver gang. Det er derfor hensigtsmæssigt, at vejlederen sikrer, at den eksterne part har realistiske forventninger til projektets resultater. 4) Der ligger naturligvis en stor indsats $i$ at etablere en kontakt til en ekstern partner, med mindre den studerende selv finder denne.

\section{Udfordringer}

På baggrund af ovenfor nævnte fordele og ulemper, samt vores mangeårige erfaringer, skal efterfølgende nævnes en række udfordringer, man som vejleder bør være opmærksom på:

- Man skal sikre sig, at de eksterne partnere har samme opfattelse af kravene til projektet som universitetsvejlederen, herunder at det planlagte projekt opfylder de relevante akademiske krav.

- Idet den studerende bliver repræsentant for uddannelsen og uddannelsesinstitutionen, er det vigtigt, at den studerende har passende modenhed, initiativ og faglige kundskaber. I modsat fald er risikoen, at den eksterne part afholder sig fra at indgå i fremtidige projekter.

- Ved mere end én vejleder kan det let ske, at summen af ansvar bliver mindre end $100 \%$ (»det sørger den anden vejleder nok for «). Det er derfor vigtigt, at den studerende selv er den drivende kraft bag selve projektet, indkaldelser til vejledermøder, opfølgning på tidsplaner, etc. Specielt hvis den studerende til daglig sidder hos den eksterne part, vil vejlederen hos denne måske i en vis grad overtage den daglige vejlederrolle, hvilket universitetsvejlederen skal gøre sig klart, så denne ikke danner sig et falsk indtryk af, at malt er i orden".

- Hvis man ikke har delt vejledningsopgaver før, er det en god idé kort at fordele rollerne mellem vejlederne: Universitetsvejlederen vil normalt sikre det faglige niveau og sociale aspekter som konflikter i gruppen etc., mens vejlederen hos den eksterne part normalt kun tager sig af faglig vejledning. ${ }^{3}$

\section{Praktiske aspekter}

Visse firmaer har som ufravigelig politik, at der skal udarbejdes en samarbejdsaftale eller fortrolighedsaftale (non-disclosure-aftale). Dette kan hurtigt blive både besværligt og tidskrævende, hvis hver ny kontrakt udarbejdet af firmaet skal gennemgås af universitetets jurister og tilpasses, før den kan underskrives. Det er her en klar fordel, hvis der kan udarbejdes en standardiseret kontrakt, så den ikke skal læses nøje igennem for hvert projekt.

På DTU har vi den regel, at afleveringsdatoen er fastsat, når projektaftalen indgås. Hvis projektet ikke afleveres til tiden, må den studerende starte forfra på et nyt projekt (udsættelse kan dog opnås, hvis særlige 
omstændigheder taler for det). Dette betyder, at projekter meget sjældent trækker ud, hvilket er til stor fordel for den studerende. Faste tidsrammer er imidlertid også bydende nødvendige ved samarbejde med eksterne partnere, da man ellers kan risikere langvarige projekter med meget lille fremdrift og deraf følgende frustrationer hos alle, inklusive den eksterne part.

\section{Overvejelser om forskel mellem en og flere studerende}

Ofte er det sådan, at de studerende, bortset fra forste semester, frit kan vælge deres makker(e) blandt medstuderende. Hvis det ikke er tilfældet, kan en række samarbejdsproblemer blive mere udtalte, men disse berøres ikke her.

Når der er mere end én projektstuderende, er det vejlederens opgave at forholde sig til, om de studerende er på omtrent samme niveau eller ej. Langt de fleste studerende vælger dog (bevidst eller ubevidst) projektdeltagere som er på nogenlunde samme faglige niveau, men måske med forskellige forcer (entreprenør, administrator, producent, integrator; teoretiker, praktiker). Herudover vælger man typisk nogen, man kan samarbejde med (»kemien« passer). I enkelte tilfælde er der dog stor forskel på det faglige niveau eller motivationen, og her må vejlederen overveje en passende fremgangsmåde til netop den gruppe. Hvis man har mistanke om konflikter, studerende der kører frihjul og lignende, kan et muligt værktøj være kravet om, at de studerende udarbejder en samarbejdskontrakt, hvor de studerende blandt andet specificerer, hvordan de vil samarbejde, og hvad de forventer af projektet og af hinanden.(Christensen, Hans Peter: Gruppearbejde - Vejledning, 2001; Bitsch Olsen, Poul og Pedersen, Kaare: Problemorienteret projektarbejde, 1997)

Det kan også forekomme, at en gruppe er enige (bevidst eller ubevidst) om samme (for) lave ambitionsniveau. Her er det specielt vigtigt, at universitetsvejlederen tager sin del af ansvaret; i denne situation vil arbejdsbyrden ofte blive »irriterende« meget større for vejlederen.

For velfungerende grupper er det generelt vores erfaring, at vejledningstiden bliver mindre for gruppen, end summen af vejledning for hver enkelt studerende, hvis disse skulle lave hvert sit projekt. Dette hænger sammen med, at man for den velfungerende gruppe kan vejlede samtlige samtidigt, hvorefter de studerende internt "fordøjer«, hvad der er blevet sagt/skrevet og i en vis udstrækning vejleder hinanden.

\section{Set fra de studerendes perspektiv}

Når vi interviewer studerende om deres oplevelser med projekter med eksterne partnere, er det er vores indtryk, at de studerende finder dette meget positivt. Det fremhæues blandt andet, at det er meget spæn- dende at arbejde med en virkelig problemstilling og dermed virkelige data, og at det giver mulighed for at få en fornemmelse af hvilke slags job, der kunne være en mulighed, når studiet er færdiggjort. De ofte nye rammer er motiverende for den studerende, og det er naturligvis udfordrende at lave et projekt, hvor man ikke har kunnet designe alting til at passe til sit eget projekt, men må leve med nogle af de givne rammer.

Disse fordele følges af en række ulemper eller udfordringer, man som studerende må gøre sig klart: Jo flere vejledere man har, og jo større fysisk afstand der er mellem disse, jo sværere kan det være at samle alle til møder. Endvidere vil man oftest tale mest med den/de vejleder(e), der sidder tæettest på, og hvis man sidder $i$ et firma, vil ens akademiske vejleder derfor let komme lidt på afstand. Det sætter krav til den studerende om at være opsøgende og selv tage initiativ til at holde kommunikationen kørende med de "fjerne" vejledere. Endvidere, hvis de forskellige vejledere trækker i hver sin retning (måske grundet modsatrettede interesser), kan det nogle gange være svært for den studerende at vælge den "rigtige«. Her bliver vejledermøder med alle implicerede vigtige.

Hvis retningslinierne for projektets udformning ikke er skrevet ned, kan man også ende i den situation, at de forskellige vejledere giver modstridende forslag/krav til fx projektrapporten.

Hvis den studerende primært udfører sit projekt på universitetet, kommer den eksterne part let på afstand; det kan til tider være svært at fă fat i denne, og der kan være lange svartider, sammenlignet med en situation hvor man er på universitetet og bare kan gå tre kontorer ned af gangen og spørge vejlederen.

De givne rammer hos en ekstern part er ikke nødvendigvis på et passende videnskabeligt niveau: fx kan eksperimentelle data være af en ikke-optimal kvalitet, fordi den akademiske og den eksterne part har forskellige prioriteter. I et sådan tilfælde kan projektet let komme til at handle om noget andet end forst planlagt.

(Det skal for en god ordens skyld fremhæeves, at ovennævnte aspekter kun findes i projekter med eksterne samarbejdspartnere.)

\section{Anbefalinger}

På baggrund af ovenstående og vores erfaringer er der en række forhold, man bør have sig for øje:

Det er vigtigt, at man får forventningerne fra vejleder/ekstern part sat passende højt i vejret: svært nok til at det bliver en stor udfordring, men samtidig skal fokus skærpes gennem projektet, så det bliver passende afgrænset og sammenhængende (hvis et projekt virker stort og uoverskueligt, er der en risiko for, at den studerende arbejder $\mathrm{i}$ flere forskellige retninger uden at kunne bringe disse sammen til sidst, hvorved 
rapporten bliver fragmenteret og måske uden solide konklusioner).

Det er vigtigt, at den studerende får en høj grad af følelse af, at han/hun er projektleder på sit eget projekt med hensyn til indhold, tidsplaner og så videre, i stedet for at den studerende nærmer sig den anden ekstrem, at "gøre hvad der bliver sagt«. En kvalificeret løsning på dette er at kræve, at den studerende selv skal formulere, skriftligt, hvad han/hun vil. Man kan udvide dette til deciderede måneds/kvartals-rapporter, hvor mål og resultater beskrives. ${ }^{4}$ Forsøg altid at sætte en deadline for et (del)mål. Fordelene er, at den studerende bliver mere motiveret fordi han/hun selv bestemmer, samtidig med at ambitionsniveauet hæves for projektet, og det bliver lettere for vejlederen at følge.

En meget vigtig detalje er det faktum, at de studerende selv vælger den eksterne partner og omvendt. Det har stor indflydelse på samarbejdet. Da man selv har valgt, vil man ofte ubevidst acceptere, at man »ligger som man har redt«. Men helt generelt er det sådan, at den studerende normalt er meget motiveret, og hvis samarbejdspartneren også er ingeniør, er der allerede en uudtalt forståelse partnerne imellem, som forebygger mange problemer.

\section{Tak}

Til Birgitte Lund Christiansen, LearningLab·DTU, for kritisk review.

\section{Litteratur}

[1] http://www.medicin-ing.dk/info_site/?projekter/2007/bsc_ projekter.html

[2] Christensen, Hans Peter: Gruppearbejde - Vejledning. CDMs skriftserie no.6., juli 2001 (se http://www.learninglab.dtu.dk/ ressourcer/publikationer.aspx).

[3] Bitsch Olsen, Poul og Pedersen, Kaare 1997: Problemorienteret projektarbejde, Samfundslitteratur, Roskilde.

\section{Noter}

1 Eksamensprojekt eller speciale

2 http://www.medicin-ing.dk/info_site/?projekter/2007/bsc_ projekter.html

3 Enneopdeling vil ofte være uudtalt og hvis man har mange af den slags projekter, skal man passe på, at det ikke bliver en vane.

4 I lighed med afviklingen af erhvervs-Ph.D.-studiet. 